\title{
Effect of CAPN3 gene genotypes on productive traits and carcass traits of broiler
}

\author{
${ }^{1}$ Iman Abdul Amir Thbit, ${ }^{2}$ Ali A. Abdulkareemm, ${ }^{3}$ Abdullah Hameed Salim \\ ${ }^{1,2,3}$ University of Thi-Qar, College of Agriculture and Marshlands, Department of Animal Production \\ 1Email: eamn3793@gmail.com \\ 2Email: ali-ah@utq.edu.iq \\ 33mail:abdallah@utq.edu.iq
}

\begin{abstract}
:
Determining the genotypes of the CAPN3 gene and studying its relationship to some economic characteristics of broiler chickens, which included weekly weights, final live weight, carcass weight and carcass parts weights, in addition to the correlation coefficient for some important Ross characteristics. 308 chickens, in which 100 chicks were bred for 35 days and taken. Primary birds were weighed and all birds were numbered. Genotypes were determined by analyzing the nitrogenous base sequences of the studied part of the CAPN3 gene the site of variation in the nitrogenous bases of the studied gene ( $\mathrm{G}>\mathrm{C} 2426)$ was diagnosed and the resulting genotypes were calculated, which are three genotypes: GG, GC, and CC of the CAPN3 gene. As for the CAPN3 gene, the results showed statistically significant differences for some traits such as chest weight and wing weight, while the results did not indicate any statistically significant differences between the three models for other traits such as live body weight, carcass, and thigh weight, back weight, weekly weights, and superiority of genotype CC on the rest of the individuals in some traits. the study suggests the possibility of using molecular markers of the CAPN3 gene in poultry breeding and selection programs.
\end{abstract}

Keyword: CAPN3 gene genotypes, broiler

\section{Introduction}

The animal production sector faces challenges all over the world, and these challenges vary according to the producing countries, whether they are developed or developing, and among these challenges are restrictions on inputs in addition to environmental demands that are imposed on management and ability to adapt, and therefore solutions must be effective for these challenges Affordable and at the forefront of technologies that contribute to maintaining animal production systems and includes information technology and genetic techniques (Bishop \& Woolliams, 2004) ,In the eighties of the last century, the names changed in all the basic sciences of genetics, biochemistry, pathology and physiology, and the discoveries in them became called new names that correspond to the wave of change in science, in the light of these changes there are the discoveries related to animal husbandry that led to a revolution in Biological techniques, including discovery of enzymes that can cleave DNA (deoxyribonucleic acid) in specific regions and discovery of vectors that can transfer DNA fragments between different organisms (Jalal and Karam, 2003) 


\section{University of Thi-Qar Journal of agricultural research}

ISSN Onlin:2708-9347, ISSN Print: 2708-9339 Volume 10, Issue 1 (2021) PP 13 -24

\section{https://jam.utq.edu.iq/index.php/main $\quad$ https://10.54174/UTJagr.Vo10.N1./02}

The improvement in the economic characteristics of an animal comes from selecting the best animals from one generation to produce the next generation, and the improvement of traits through selection from one generation to another reflects the effectiveness of selection criteria in determining the genetic superiority of the next generation. An animal in those traits (Falconer \& Mackay, 1996) ,There are some traits that are difficult to measure by phenotype selection and therefore difficult to improve when the genetic variance that causes phenotype variation is relatively small (Falconer and Mackay, 1996) ,Therefore, selecting animals on the basis of phenotype may lead to the selection of animals with high values of traits perhaps because they have undergone a good environment, not because they carry superior genes, so the improvement through phenotypic selection over low heritability will be small, as some traits are measured Productivity at a later age of the animal, which requires keeping all animals for a long period of time before excluding non-selected animals, while early selection reduces the number of animals that must be kept until the measurement age of the trait of interest, thus reducing the cost of the breeding program and maintaining selection efficiency (Cahaner and Nitsan, 1985.Therefore, molecular gene selection is the best option when the phenotype is inaccurate for genotype assessment as well as difficult and costly to measure (Dekkers and Hospital, 2002)

Several genes are used as markers in selection programmes, including those of the calpain family, including the gene we addressed in our study, the CAPN3 gene, or previously called p94, the skeletal muscle isoform that encodes the enzyme calpain3 (Partha et al., 2014) .Accordingly, this study aims to reveal the morphology of the CAPN3 gene as a candidate gene to see if it is related to the economic characteristics of broiler chickens and to ensure that it can be used as a genetic marker in breeding and improvement programmes, in addition to identifying some genetic markers for the studied gene and ascertaining their relationship to production traits. Carcass recipes for broilers.

\section{Materials and Methods:}

\section{A. Field of study}

The study was conducted in the poultry field of the College of Agriculture and the Marshes of Thi Qar University for the period from (9/11/2020) to (13/2/2021) (included field and laboratory work). as 100 chicks of Rose 308 strain of one day old were raised on the floor. The birds were numbered by the legs, and the fieldwork continued for 35 days. The chicks were fed for the duration of the experiment on a starter and growth diet and a special preventive health program was used for them. The chicks were weighed at the initial weight individually weekly and the final weight before slaughter after fasting the birds for 10 hours. Blood samples were taken for the purpose of separating the genetic material DNA Determining the genetic structures of the CAPN3 gene from broilers (Ross 308) and studying their relationship to some traits of broilers. 


\section{B. Carcass measurements}

The live body was weighed and after slaughter the carcass was weighed and the carcass was cut to take the weight of its main parts (chest and thighs) in addition to the secondary parts (back and wings) and the weight of belly fat.As for the laboratory work, it was conducted in the laboratory of the Department of Biological Sciences at Thi Qar University.

The blood samples were collected from 100 broiler birds and placed in tubes containing an anticoagulant substance (EDTA K2), then the samples were transferred in a cooler box and kept at a $\left(-20^{\circ}\right)$ Temperature for the extraction of DNA. The DNA was extracted from bird samples according to the instructions of the diagnostic kit (kit supplied by Promega Company), then the process of electrophoresis of the DNA was carried out using the method (Sambrook, 2001)

\begin{tabular}{|l|l|l|l|l|l|l|}
\hline Gene & $\begin{array}{l}\text { Oilgo } \\
\text { nucleotides }\end{array}$ & $\mathrm{Tm}^{\circ}$ & GC $\%$ & $\begin{array}{l}\text { Product } \\
\text { size }\end{array}$ & $\begin{array}{l}\text { Sequence } \\
\left(5^{\prime}-3^{\prime}\right)\end{array}$ & Ref. \\
\hline CAPN3 & Forward primer & 59.82 & 60.00 & $1049 \mathrm{bp}$ & $\begin{array}{l}\text { GGGTGGGAAATAGAGC } \\
\text { CAGG }\end{array}$ & NCBI \\
\hline & Reverse primer & 59.93 & 47.62 & & $\begin{array}{l}\text { TTCGGAGTGTATTTTGG } \\
\text { GGCA }\end{array}$ & NCBI \\
\hline
\end{tabular}

Table (1) Sequencing of primers used and prepared by (Researcher Co.Ltd Iraq)

In order to perform the molecular detection and genotyping of the CAPN3 gene, its primers were designed as shown in Table (1). The target fragment of the CAPN3 gene was amplified using PCR technology, and this reaction was performed under the conditions described in Table (2), then migrated to the PCR product with cut-offs of known size (100-2000 tags). The voltage of the device was set at 50V for 1.5 hours and photographed. Then the amplification product of the studied samples with the primers was sent to the Korean company (Macrogene) to obtain the real sequence of the study gene and sequence analysis to determine the genotypes of the gene under study 
Table (2): The program prepared for the PCR technique

\begin{tabular}{|l|l|l|l|l|}
\hline No & Steps & $\mathrm{C}^{0}$ & Cycles & Time \\
\hline 1 & Pre-Denaturation & $94^{\circ}$ & 1 & $5 \mathrm{~min}$ \\
\hline 2 & Denaturation & $94^{\circ}$ & & $1 \mathrm{~min}$ \\
\hline 3 & Annealing & $58^{\circ}$ & 30 & $45 \mathrm{sec}$ \\
\hline 4 & Extension & $72^{\circ}$ & & $1 \mathrm{~min}$ \\
\hline 5 & Final Extension & $72^{\circ}$ & 1 & $10 \mathrm{~min}$ \\
\hline 6 & Cooling & $4^{\circ}$ & 1 & \\
\hline
\end{tabular}

\section{Analysis Statistica}

The data was statistically analyzed using the statistical program System SAS (Statistical Analysis)(2012) and random design (CRD) to study the effect of the polymorphism of the studied gene CAPN3 on the traits of Ross 308 broilers and the significant differences between the means were compared using Duncan's test (1955)

Mathematical model: $Y i j=\mu+G i+e i j$

Yij: The observation value (j) due to genotype (i), ( $\mu$ ) overall mean of the trait, (Gi) effect of genotypes (GG, $\mathrm{GC}, \mathrm{CC}$ ) of CAPN3 gene in Ross 308, and (eij) normally distributed random error with mean equal to zero and variance of e $\sigma 2$.also used chi-square test(Chi-square- $\chi 2)$ to compare the percentages of the distribution of genotypes for the studied gene. 


\section{Results:}

Figure (1) shows the result of migrating the PCR product with (100-2000 Marker) on agarose gel for the target segment of the CAPN3 gene, as the required segment size (1040 pb) was obtained

\section{Figure( 1): PCR product of CAPN3 gene}

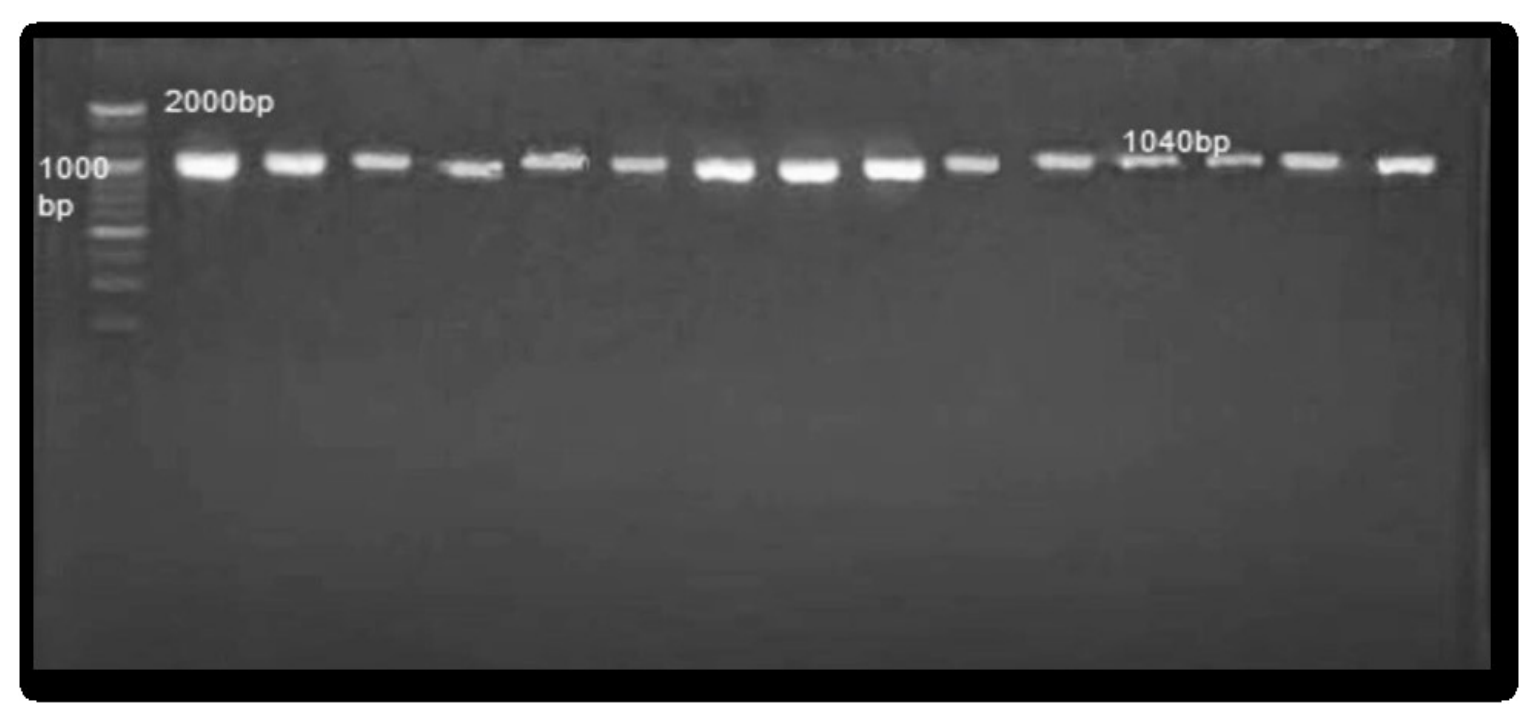

According to NCBI, the results of analysis of Ross 308 broiler sequencing, specifically at the 2426 mRNA locus of the complete CAPN3 gene, when comparing the studied piece (1040 pb) of the CAPN3 gene with the 2426 mRNA locus of the entire CAPN3 gene, a SNP $(2426 \mathrm{G}>\mathrm{C})$ that occurs in This site is from exon (21) of the CAPN3 gene, and as a result of this difference, the glutamic acid in the protein sequence (735) changed to glutamine, Figure 2 shows the location of the $\mathrm{G}<\mathrm{C}$ difference of the studied segment of the CAPN3 gene.

Table No. (3) shows the genotypes and their proportions of CAPN3 gene in broiler chickens, which were determined based on the difference in the base $\mathrm{G}>\mathrm{C}$, which showed statistically significant differences at the level ( $\mathrm{p} \leq 0.01)$ where $\mathrm{G}$ represents the most common allele in experimental samples with a frequency ( 0.60$)$, while the $\mathrm{C}$ allele is the least common with a frequency of $(0.40)$

Previous research adopted the RFLP technique to determine the polymorphism of the CAPN3 gene, so we preferred to adopt the (sequencing) technique in determining the genotypes of the CAPN3 gene and designing an initiator that includes the largest possible region of the gene, which included 3 exons and a number of introns, Figure (2) represents the site of variation in the segment studied for the gene 
Table 3: Pedigrees of CAPN3 . genotypes

\begin{tabular}{|l|l|}
\hline Genotypes & Frequency \\
\hline GG & 0.28 \\
\hline GC & 0.65 \\
\hline CC & 0.07 \\
\hline & $100 \%$ \\
\hline Chi-Square & $37.547^{* *}$ \\
\hline Probability & $(p \leq 0.01)^{* *}$ \\
\hline
\end{tabular}

The studied segment represents a large region (1040bp) of the size of the CAPN 3 gene, which included three exons in addition to parts of introns.

The SNP has been registered on the NCBI website for genotypes (GG, GC, CC) in the gene bank under the accession numbers:

(GG :- LC640091, GC :- LC640092, CC :- LC640093 ) Respectively, it is the first SNP recorded at this site of the CAPN 3 gene, The figure (2) shows the location of the variation occurring in the studied piece (1040bp). 


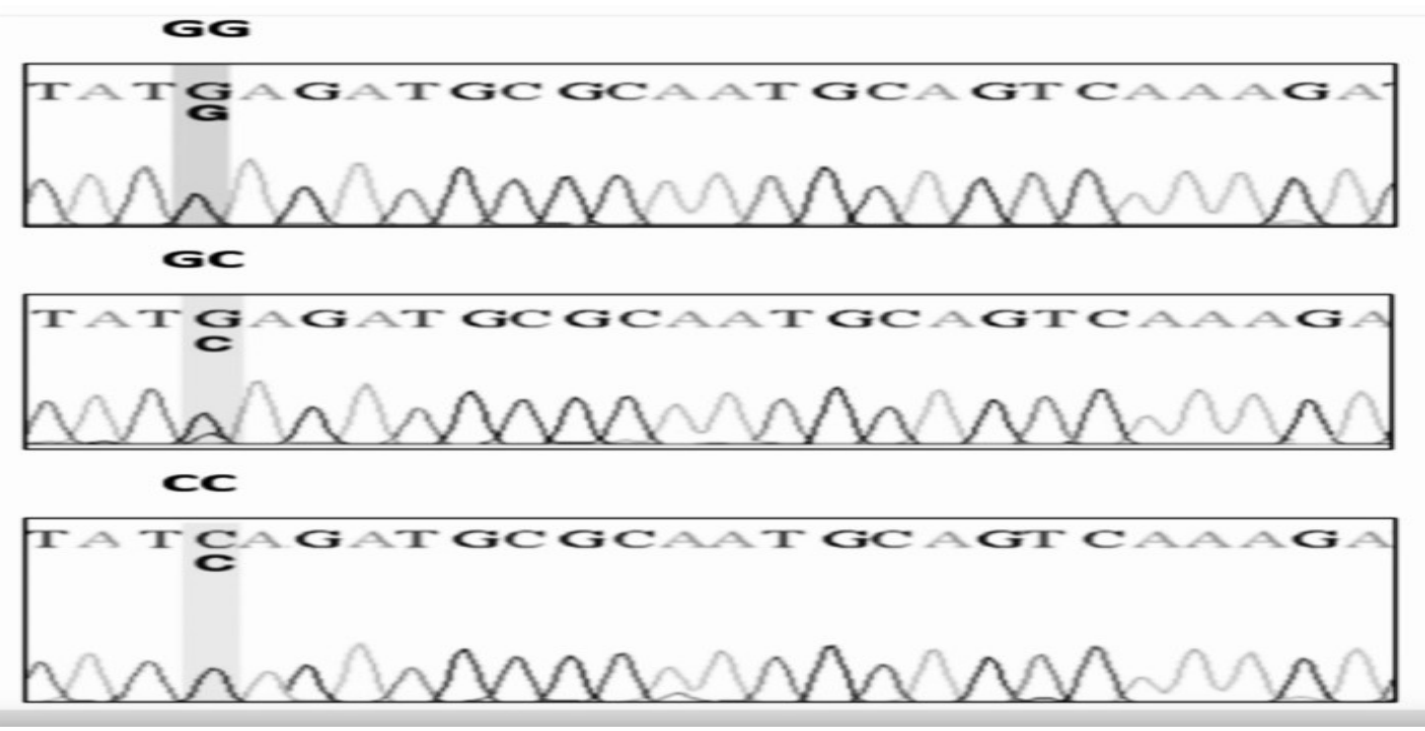

A. Genotype of the CAPN3 gene and its relationship with weekly weights and final live body weight of Ross 308 broilers.

In the table (4) no significant differences in weekly weights were observed between CAPN 3 genotypes, but it turned out that in the first week the GC genotype had the highest weight, then after the third week the weight trend was in favor of the CC genotype, which was the highest weight until Last week of the experiment, indicating that the highest weight was in favor of the CC genotype, followed by the GG genotype, while GC was the lowest. The results agreed with (Zhang et al., 2012) who confirmed that the growth phase from 2 to 8 weeks is an important period for muscle fiber development. He also indicated that the level of gene expression of 3 CAPN was prevalent during that period, and muscle growth will reflect positively on the weight rate and this is what was observed during our study.

Table(4) Means ( \pm ) standard error of each of the weekly weights and the final weight for the genotype of the CAPN3 gene for Ross 308 broilers

\begin{tabular}{|l|l|l|l|l|l|}
\hline \multicolumn{2}{|l|}{ Means \pm standard error } \\
\hline Genotype & first week & second week & third week & fourth week & final week \\
\hline GG & 142.08 & 341.67 & 708.08 & 1232.67 & 2001.58 \\
& $5.28 \pm$ & $16.52 \pm$ & $35.06 \pm$ & $55.804 \pm$ & \pm 80.21 \\
\hline
\end{tabular}




\begin{tabular}{|c|c|c|c|c|c|}
\hline GC & $\begin{array}{l}154.36 \\
4.025 \pm\end{array}$ & $\begin{array}{l}366.14 \\
17.82 \pm\end{array}$ & $\begin{array}{l}729.79 \\
39.79 \pm\end{array}$ & $\begin{array}{l}1254.96 \\
58.367 \pm\end{array}$ & $\begin{array}{l}1887.14 \\
\pm 58.03\end{array}$ \\
\hline \multirow[t]{2}{*}{ CC } & $\begin{array}{l}135.67 \\
14.81 \pm\end{array}$ & $\begin{array}{l}336.00 \\
42.77 \pm\end{array}$ & $\begin{array}{l}803.33 \\
89.69 \pm\end{array}$ & $\begin{array}{l}1466.00 \\
118.05 \pm\end{array}$ & $\begin{array}{l}2066.67 \\
\pm 194.20\end{array}$ \\
\hline & N.S & N.S & N.S & N.S & N.S \\
\hline \multicolumn{6}{|c|}{$\begin{array}{l}\text { The averages with different letters within the same column differ significantly. N.S indicates } \\
\text { that there are no significant differences of one column. }\end{array}$} \\
\hline
\end{tabular}

\section{B. Genotype of the CAPN3 gene and its relationship to the carcass characteristics of broilers Ross 308}

The results (shown in Table 5) indicate that there were no significant differences in vivo and carcass weight between the genotypes resulting from the SNP obtained from nitrogenous base sequencing analysis and this is in agreement with the results of Felício et al. (2013)

The results of the current study also showed significant differences in chest weight, where the genotype (CC) outperformed the genotype (GC), while the genotype of GG did not differ significantly from the other two types and the results are agreed with Abdullah, (2016) and Zhang et al (2012) who found that the highest level of CAPN3 gene expression was found in the pectoral muscle compared to the rest of the tissues, and indicated that an increase in the CAPN3 gene leads to a change in muscle fiber protein. CAPN3 gene expression is associated with muscle fiber development and thus plays an important role in regulating and increasing muscle mass in chickens. While our results did not agree with those of Felício et al. (2013) who did not find differences in gene expression in the chest muscle, but found statistically significant differences in the thigh, which did not agree with the results of our study as no significant difference was observed in the thigh and back muscle between the genetic structures of the study gene unlike the wings where it showed RESULTS Significant differences between CAPN3 genotypes. The reason for ethical differences in some parts of the carcass, including the breast and wings, is probably due to the effect of the amino acid glutamine which affects muscle building and thus improves carcass properties in broiler chickens, he explained. The Researcher (2019). ). Al Julibor and others. When glutamine acid is used as a food supplement for chickens, it has a role in the characteristics of the carcass, especially the breast and wings, and the positive effect of 
glutamine on the digestive system, as it increases the length of the intestinal villi. Which is reflected in the process of digestion and absorption and thus increases muscle mass and weight, also, the results of the study did not show any significant difference for belly fat between the genotypes of the study gene.

Table(5) Means ( \pm ) standard Carcass weight and its fractions for CAPN3 gene genotypes of Ross 308

\begin{tabular}{|c|c|c|c|c|c|c|}
\hline \multicolumn{7}{|c|}{ Means \pm standard error } \\
\hline Genotype & $\begin{array}{l}\text { Carcass weight } \\
(\mathrm{gm})\end{array}$ & $\begin{array}{l}\text { Fat weight } \\
(\mathrm{gm})\end{array}$ & $\begin{array}{l}\text { Chest } \\
\text { weight } \\
\text { (gm) }\end{array}$ & $\begin{array}{l}\text { thigh } \\
\text { weight } \\
\text { (gm) }\end{array}$ & $\begin{array}{l}\text { Wing } \\
\mathrm{s} \\
\text { weigh } \\
\mathrm{t} \\
(\mathrm{gm})\end{array}$ & $\begin{array}{l}\text { Back } \\
\text { weight } \\
\text { (gm) }\end{array}$ \\
\hline $\mathrm{CC}$ & $\begin{array}{l}1611.33 \\
\pm 89.698\end{array}$ & $\begin{array}{l}23.33 \\
\pm 0.667\end{array}$ & $\begin{array}{l}{ }^{a} 638.33 \\
\pm 17.401\end{array}$ & $\begin{array}{l}239.33 \\
\pm 20.019\end{array}$ & $\begin{array}{l}{ }_{172} \\
67 \\
\pm 8.7 \\
62\end{array}$ & $\begin{array}{l}267.33 \\
\pm 39.34 \\
6\end{array}$ \\
\hline GC & $\begin{array}{l}1387.68 \\
\pm 42.396\end{array}$ & $\begin{array}{l}24.68 \\
\pm 1.898\end{array}$ & $\begin{array}{l}{ }^{b} 510.71 \\
\pm 23.400\end{array}$ & $\begin{array}{l}217.91 \\
\pm 9.537\end{array}$ & $\begin{array}{l}\mathrm{b}_{133 .} \\
93 \\
\pm 4.0 \\
68\end{array}$ & $\begin{array}{l}240.57 \\
\pm 10.02 \\
3\end{array}$ \\
\hline GG & $\begin{array}{l}1519.00 \\
\pm 67.607\end{array}$ & $\begin{array}{l}27.75 \\
\pm 2.508\end{array}$ & $\begin{array}{l}{ }^{a b} 615.25 \\
\pm 20.971\end{array}$ & $\begin{array}{l}224.17 \\
\pm 12.320\end{array}$ & $\begin{array}{l}{ }^{\mathrm{b}} 133 . \\
67 \\
\pm 6.3 \\
73\end{array}$ & $\begin{array}{l}257.67 \\
\pm 17.71 \\
0\end{array}$ \\
\hline & N.S & N.S & ** & N.S & ** & N.S \\
\hline
\end{tabular}

\section{Pearson Correlation of Economic Attributes}

Table (6) shows the Pearson correlation coefficient for some economic traits and the extent of the correlation between those important traits such as (live body weight, carcass weight, chest weight, thigh weight, wing weight, and abdominal fat). The results showed a positive and strong correlation with average body weight. The live body weight was with the weight of the carcass, chest, thighs, wings and belly fat weight, and it was significant, as the highest correlation of live body weight with the carcass weight was (0.952), and the lowest correlation with the carcass weight. Belly fat (0.508), while carcass weight as well as its positive correlation with live body weight, the results showed a strong correlation with chest weight $(0.874)$, thighs weight and wings weight, and the lowest correlation was with belly fat. (0.465) and had a statistically significant difference. As for chest weight as well as its high correlation with body weight and carcass weight, the results 


\section{University of Thi-Qar Journal of agricultural research}

ISSN Onlin:2708-9347, ISSN Print: 2708-9339 Volume 10, Issue 1 (2021) PP 13 -24

\section{https://jam.utq.edu.iq/index.php/main $\quad$ https://10.54174/UTJagr.Vo10.N1./02}

showed its positive correlation with thigh weight and wing weight, which had a strong correlation with thighs (0.690) as well, higher than its correlation with thighs weight. Chest weight (0.504), and the lowest correlation between wings and belly fat (0.320), as it is clear from the table (6) .All or most of the connections were highly significant.

Table(6) Pearson Correlation for some economic traits of broilers

\begin{tabular}{|c|c|c|c|c|c|c|c|}
\hline \multicolumn{8}{|c|}{ Correlations } \\
\hline & & $\begin{array}{l}\text { Live } \\
\text { weight } \\
\text { (gm) }\end{array}$ & $\begin{array}{l}\text { Carcass } \\
\text { weight } \\
(\mathrm{gm})\end{array}$ & $\begin{array}{l}\text { Fat weight } \\
\text { (gm) }\end{array}$ & $\begin{array}{l}\text { Chest } \\
\text { weight } \\
\text { (gm) }\end{array}$ & $\begin{array}{l}\text { thigh } \\
\text { weight }\end{array}$ & $\begin{array}{l}\text { Wings weight } \\
\text { (gm) }\end{array}$ \\
\hline \multirow{2}{*}{$\begin{array}{l}\text { Live } \\
\text { weight } \\
\text { (gm) }\end{array}$} & $\begin{array}{l}\text { Pearson } \\
\text { Correlation }\end{array}$ & & $0.952^{* *}$ & $0.508^{* *}$ & $0.878^{* *}$ & $0.742^{* *}$ & $0.671^{* *}$ \\
\hline & Sig. (2-tailed) & & 0.000 & 0.001 & 0.000 & 0.000 & 0.000 \\
\hline \multirow{2}{*}{$\begin{array}{l}\text { Carcass } \\
\text { weight } \\
(\mathrm{gm})\end{array}$} & $\begin{array}{l}\text { Pearson } \\
\text { Correlation }\end{array}$ & $0.952^{* *}$ & & $0.465^{\star *}$ & $0.874^{* *}$ & $0.782^{* *}$ & $0.713^{* *}$ \\
\hline & Sig. (2-tailed) & 0.000 & & 0.002 & 0.000 & 0.000 & 0.000 \\
\hline \multirow{2}{*}{$\begin{array}{l}\text { Fat } \\
\text { weight } \\
\text { (gm) }\end{array}$} & $\begin{array}{l}\text { Pearson } \\
\text { Correlation }\end{array}$ & $0.508^{* *}$ & $0.465^{* *}$ & & $0.467^{* *}$ & $0.320^{*}$ & $0.302^{*}$ \\
\hline & Sig. (2-tailed) & 0.001 & 0.002 & & 0.002 & 0.036 & 0.049 \\
\hline \multirow{2}{*}{$\begin{array}{l}\text { Chest } \\
\text { weight } \\
\text { (gm) }\end{array}$} & $\begin{array}{l}\text { Pearson } \\
\text { Correlation }\end{array}$ & $0.878^{* *}$ & $0.874^{* *}$ & $0.467^{* *}$ & & $0.504^{* *}$ & $0.557^{\star *}$ \\
\hline & Sig. (2-tailed) & 0.000 & 0.000 & 0.002 & & 0.001 & 0.000 \\
\hline \multirow{2}{*}{$\begin{array}{l}\text { thigh } \\
\text { weight }\end{array}$} & $\begin{array}{l}\text { Pearson } \\
\text { Correlation }\end{array}$ & $0.742^{* *}$ & $0.782^{* *}$ & $0.320^{*}$ & $0.504^{* *}$ & & $0.690^{* *}$ \\
\hline & Sig. (2-tailed) & 0.000 & 0.000 & 0.036 & 0.001 & & 0.000 \\
\hline \multirow{2}{*}{$\begin{array}{l}\text { Wings } \\
\text { weight } \\
\text { (gm) }\end{array}$} & $\begin{array}{l}\text { Pearson } \\
\text { Correlation }\end{array}$ & $0.671^{* *}$ & $0.713^{* *}$ & $0.302^{*}$ & $0.557^{* *}$ & $0.690^{* *}$ & \\
\hline & Sig. (2-tailed) & 0.000 & 0.000 & 0.049 & 0.000 & 0.000 & \\
\hline
\end{tabular}

In addition to the effect of the CAPN3 gene on muscle tissue growth as shown by previous studies, it is possible that the differences in some characteristics of the carcass in this study are due to the change of the amino acid glutamine (Gln) that resulted from the variation in the gene, which may have affected the energy supply of the bird's body, Which helps store glycogen, affects muscle building and repair, and thus increases breast weight and mass in broiler chickens (Salmanzadeh et al., 2016). The researcher (Gholipour et al., 2019) showed that glutamine acid has a role in the characteristics of the carcass, as he showed that the chest and wings were higher in the treatments in which glutamine was used as food. A supplement to chicken, in addition to the positive effect of acid on the growth of the digestive system and has a role in the synthesis and 
analysis of muscle protein, thus increasing muscle mass and weight, as glutamine leads to an increase in gene expression and biological activity of secreted enzymes, and this supports our findings, as amino acids change It may improve carcass properties and lead to a marked increase in pectoral muscle and wings as well as the effect of glutamine on the digestive system.

\section{Conclusions.}

These traits can be improved by selecting animals that carry distinctive genetic traits by searching for genetic loci that contain genes that have a role or are responsible for the desired traits, so the study of candidate genes is one of the most important means to determine whether these genes are associated with the traits studied. Previous studies have demonstrated the association of CAPN3 gene expression with muscle growth and regulation in chickens (Zhang et al., 2012). In this study, we identified several genotypes of the CAPN3 gene by sequencing and obtained a new variation (SNP) $(2426 \mathrm{G}>\mathrm{C})$, which was recorded in .(NCBI)

\section{References}

1- Abdullah, O.M. 2016. Relationship of CAPN1 and CAPN3 genes and their sequences and their relationship to a number of carcass traits for broilers (Ross 308). Master thesis, Department of Livestock, College of Agriculture, University of Anbar.

2-Cahaner, A., Nitsan, Z., 1985. Evaluation of Simultaneous Selection for Live Body Weight and Against Abdominal Fat in Broilers. Poult. Sci. 64, 1257-1263 https://www.sciencedirect.com/science/article/pii/S0032579119468661?via\%3Dihub

3-Falconer, D., Mackay, T., 1996. Introduction to quantitative genetics., 4th edn (Longmans Green: Harlow, UK)

4-Felício, A.M., Boschiero, C., Balieiro, J.C.C., Ledur, M.C., Ferraz, J.B.S., Michelan Filho, T., Moura, A.S.A.M.T., Coutinho, L.L., 2013. Identification and association of polymorphisms in CAPN1 and CAPN3 candidate genes related to performance and meat quality traits in chickens. Genet. Mol. Res. 12, 472-482.

\section{https://doi.org/10.4238/2013.February.8.12}

5-Galal, Salah and Hassan Karam. 2003 . animal husbandry Cairo, Anglo-Egyptian Library, sixth edition.

6-Kokoszyński, D., Bernacki, Z., Saleh, M., Stęczny, K., Binkowska, M., 2017. Body Conformation and Internal Organs Characteristics of Different Commercial Broiler Lines. Rev. Bras. Ciênc. Avícola 19, 47-52. 
University of Thi-Qar Journal of agricultural research

ISSN Onlin:2708-9347, ISSN Print: 2708-9339 Volume 10, Issue 1 (2021) PP 13 -24

https://jam.utq.edu.iq/index.php/main $\quad$ https://10.54174/UTJagr.Vo10.N1./02

https://www.scielo.br/j/rbca/a/p3c9hJfwPK7FHwK6H35P6my/?lang=en

7-Le Bihan-Duval, E., Mignon-Grasteau, S., Millet, N., Beaumont, C., 1998. Genetic analysis of a selection experiment on increased body weight and breast muscle weight as well as on limited abdominal fat weight. Br. Poult. Sci. 39, 346-353.

8-Salmanzadeh, M., Ebrahimnezhad, Y., Aghdam Shahryar, H., Ghiasi Ghaleh-Kandi, J., 2016. The effects of in ovo feeding of glutamine in broiler breeder eggs on hatchability, development of the gastrointestinal tract, growth performance and carcass characteristics of broiler chickens. Arch. Anim. Breed. 59, 235-242.

https://aab.copernicus.org/articles/59/235/2016/

9-Sambrook, J. and Russel, D. 2001. Molecular cloning: a laboratory.

10-SAS. 2012. Statistical Analysis System, User's Guide. Statistical. Version 9.1th ed. SAS. Inst. Inc. Cary. N.C. USA.

11-Zhang, Z.-R., Liu, Y.-P., Yao, Y.-G., Jiang, X.-S., Du, H.-R., Zhu, Q., 2009. Identification and association of the single nucleotide polymorphisms in calpain3 (CAPN3) gene with carcass traits in chickens. BMC Genet. 10, 10 .

https://bmcgenomdata.biomedcentral.com/articles/10.1186/1471-2156-10-10

12-Zhang, Z.-R., Zhu, Q., Yao, Y.-G., Jiang, X.-S., Du, H.-R., Liu, Y.-P., 2012. Characterization of the expression profile of calpain-3 (CAPN3) gene in chicken. Mol. Biol. Rep. 39, 3517-3521.

https://link.springer.com/article/10.1007\%2Fs11033-011-1124-4 